Asian Pacific Journal of Reproduction

Journal homepage: www.apjr.net

\title{
Morphological and functional alterations of female reproduction after regular exposure of bamboo shoots of North East India
}

\author{
Deotima Sarkar, Arijit Chakraborty, Dakshayani Mahapatra, Amar K Chandra \\ Endocrinology and Reproductive Physiology Laboratory, Department of Physiology, University of Calcutta; 92, APC Road,Kolkata-700 009
}

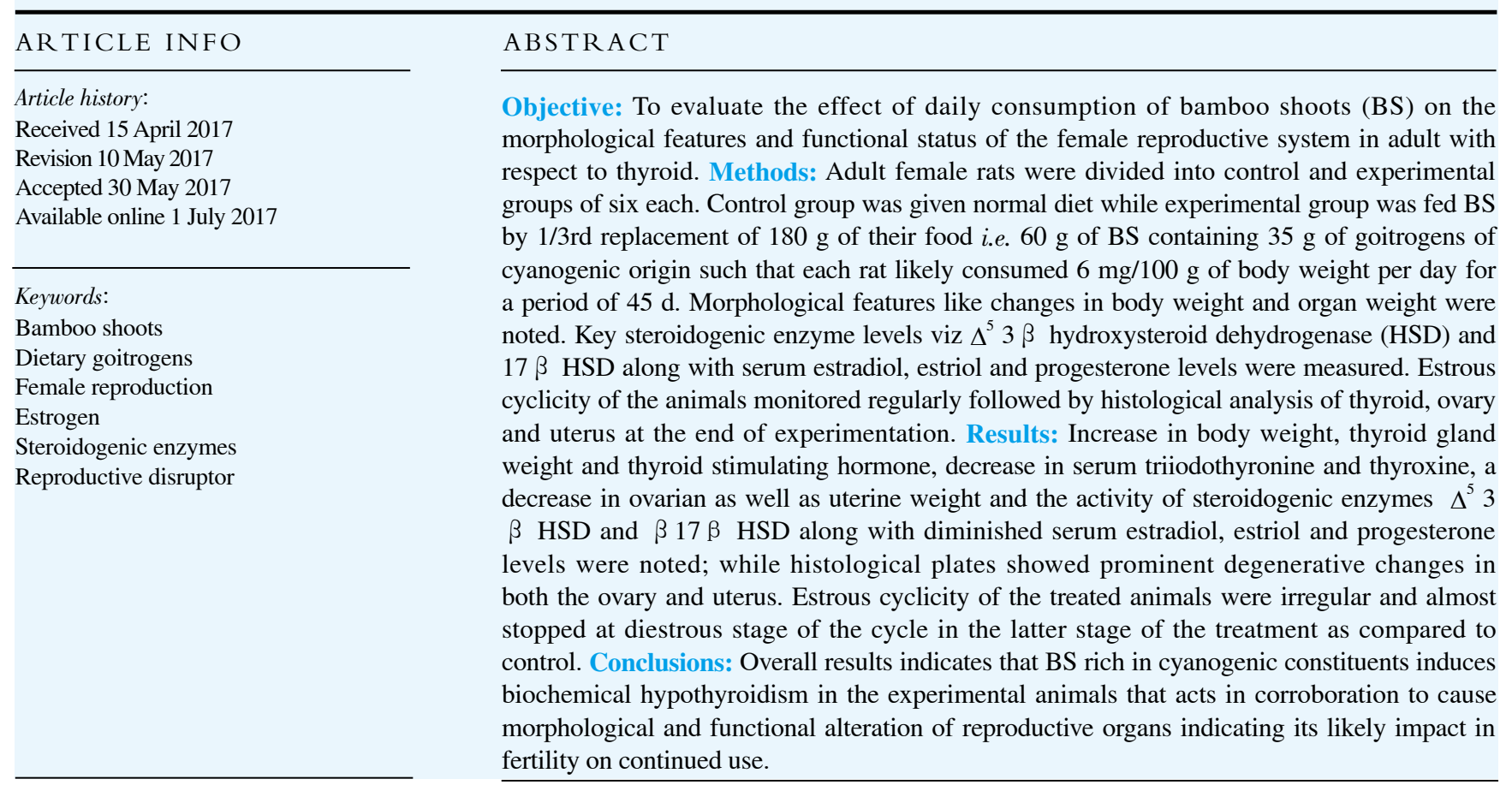

\section{Introduction}

The female reproductive system is designed to carry out many functions, the most important of which is preservation of fertility[1]. The female reproductive system is concerned with maintenance of morphological female characters and ovulation; maintenance of menstrual cyclicity, implantation, pregnancy, birth, lactation and menopause are important processes of the functionality of this system[2]. Several endogenous[3-6] and exogenous factors[7,8] regulate the normal functioning of the female reproductive system like follicle stimulating hormone[3], luteinizing hormone, thyroid hormone[6], food consumed[9], stress and environmental pollutants, etc. Bamboo-shoots (BS) are one such consumed cruciferous

Corresponding author: Prof. Amar K Chandra, Endocrinology and Reproductive Physiology Laboratory, Department of Physiology, University of Calcutta 92, APC Road, Kolkata-700009.

Fax: 91-033-2351-9755

Tel: 9433161840

E-mail: physiology.ac@gmail.com

Foundation project: This work was financially supported by the University of Calcutta, and the Grant number was BI 92(5). vegetable which are once popular in the eastern region of the world. And now they gain worldwide acclaim as a healthy food and herbal medicine. Commonly known for their industrial uses, a rare known fact of bamboos is the use of its young shoots as a food that can be eaten fresh, fermented, or canned[10]. BS is used for traditional preparations of pickles, salads, curries, soups and in modern eatables like breakfast cereals, fruit juices, bakery and meat products, sauces, shredded cheeses, cookies, pastas, snacks, frozen desserts, and many other food products[11,12]. The young shoots are not only delicious but are rich in nutrient, mainly proteins, carbohydrates, minerals, and fibers and are low in fat[13,14]. In addition, they contain phytosterols[15] and a high amount of fiber

This is an open access article distributed under the terms of the Creative Commons Attribution-Non Commercial-Share Alike 3.0 License, which allows others to remix, tweak and buid upon the work non-commercially, as long as the author is credited and the new creations are licensed under the identical terms.

For reprints contact: reprints@medknow.com

C2017 Asian Pacific Journal of Reproduction Produced by Wolters Kluwer- Medknow

How to cite this article: Deotima Sarkar, Arijit Chakraborty, Dakshayani Mahapatra, Amar K Chandra. Morphological and functional alterations of female reproduction after regular exposure of bamboo shoots of North East India. Asian Pac J Reprod 2017; 6(4): 151-157. 
aids their labelling as nutraceuticals or natural medicines that are creating ripples among health advocates and scientists alike. Recent studies have also revealed that BS has a number of health perks: increasing appetite and digestion, reducing obesity and risks of cardiovascular disease[16] as well as anti-cancer constituents[17-20].

In opposition to all the nutraceutical advantages of BS, it is an acknowledged natural goitrogen with anti-thyroidal constituents like cyanogenic glycosides[21], glucosinolates and thiocyanates[22] and has been reported to cause endemic goiter in Manipur, North East, and India on regular consumption even in presence of adequate iodine[23]. Hypothalamic-pituitary-thyroid axis and hypothalamicpituitary-ovarian axis function in close conjunction and as thyroid hormone receptors exist in the ovarian tissue; several instances of hypothyroidism causing reproductive disturbances are available including menstrual cycles characterized mainly by polymenorrhea, especially anovulatory cycles[24] and an increase in fetal wastage in mature women[25]. Changes in sex hormone-binding globulin, prolactin, gonadotropin-releasing hormone, and sex steroid serum levels are also associated with dysfunction of the thyroid gland[26]. Abnormalities in thyroid hormone levels can thus greatly influence fertility in both sexes. BS has also been reported to induce infertility in male rats[27] and is used widely in third world country tribes to ameliorate several reproductive problems[28].

The effect of sub-chronic exposure of BS in female reproduction is yet to be clearly elucidated experimentally and no conclusive experimental or clinical data is available about its effects on female reproduction on regular ingestion. Its indigenous uses by various communities further fuel the cause of potentiating the exact role that BS plays over the female reproductive system. Moreover as mentioned BS has anti-thyroid properties, indicating that it is likely to have an impact on the female reproductive system through suppression of secretion of thyroid hormones. On attaining clear information regarding its effect on the female reproductive system, inkling to how on consumption of natural goitrogens like BS induces changes in female reproduction can also be perceived. The present investigation has therefore been undertaken to study the changes in morphological and functional status of the female reproductive system on BS consumption.

\section{Materials and methods}

\subsection{Animals}

For investigation, 12 adult female rats ( 6 for experimental and 6 for control studies) weighing $(90 \pm 10) \mathrm{g}$ were used. The animals were maintained as per national guidelines and protocols as approved by the Institutional Ethics Committee of the Department of Physiology, University of Calcutta. They were housed in two cages having six

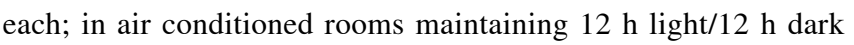
cycles. The rats were allowed free access to drink water and were fed on standardized normal laboratory diet (20\% protein) which consisted of $70 \%$ wheat, $20 \%$ Bengal gram, $5 \%$ fish meal powder, $4 \%$ dry yeast powder, $0.75 \%$ refined til oil and $0.25 \%$ shark liver oil with required amount of potassium iodide[29]. Control rats were fed a normal laboratory diet and experimental group was fed BS as mentioned below for $45 \mathrm{~d}$.

\subsection{Preparation of bamboo shoot containing food[22]}

The experimental group of rats was fed BS by replacing 1/3rd portion of normal diet. Sixty gram of BS were weighed, equal amount of water was added to it and boiled for $15 \mathrm{~min}$. It was then mixed with $180 \mathrm{~g}$ of normal food as mentioned. Thus, $60 \mathrm{~g}$ of BS containing near to $35 \mathrm{mg} / 100 \mathrm{~g}$ of goitrogens was given to six rats, such that ideally, 6 rats received a daily dose of $6 \mathrm{mg} / 100 \mathrm{~g}$ of body weight antithyroid substances.

\subsection{Food consumption pattern[30]}

Food consumption of each rat per day was recorded daily during the period of treatment. Calculation of food consumption for each rat (g/rat/day) was calculated as:

Food given $(\mathrm{g})-$ Food wasted $(\mathrm{g})=$ Food consumption $(\mathrm{g})$

\subsection{Measurement of urinary iodine and thiocyanate}

Urine samples were collected by placing animals in metabolic cages. The urine samples were ashed after digestion, and iodide was estimated by its catalytic action on the reduction of ceric ion $\mathrm{Ce}^{+2}$ to cerous ion $\mathrm{Ce}^{+3}$, maintaining internal quality control by the method of Karmakar et al.[31].

Thiocyanate concentrations in urine samples were measured using the method of Aldridge[32] as modified by Michajlovskij et al.[33].

\subsection{Study of estrous cycle of female rats[34]}

Normal saline $(0.9 \%)$ was taken in a blunt tipped dropper and was pushed into vagina of each rat of both the experimental as well as the control groups. A smear was obtained by spreading on a slide. The smear was dried and then stained using hematoxylin-eosin. The slide was then observed under a microscope to identify the stage of estrous cycle. The entire protocol was performed for 45 consecutive days and the data was recorded.

\subsection{Sacrifice of the animal}

The animals were sacrificed on the consecutive day of the last treatment following IEC protocol. Blood was collected from the hepatic portal vein of each animal and stored separately. Before sacrifice the body weight of each rat was taken. The ovaries and uterus from each animal was collected and stored separately.

\subsection{Histological study}

On the day of sacrifice, thyroid, ovary and uterus of both experimental and control groups of animals were removed, weighed and fixed in Bouin's solution. The tissues were embedded in paraffin and sectioned on a microtome. The sections were stained in hematoxylin-eosin and observed under a light microscope (Model -CH20i Olympus; serial number 8A06177) at $400 \times$ and $100 \times$ as required. The photomicrograph of the sections were taken using 
the Nikon Cool Pix P1 500 Digital Camera.

\subsection{Assay of $3 \beta$ hydroxysteroid dehydrogenase (HSD) and $17 \beta$ HSD activity[35,36]}

The ovarian tissue was homogenized with a fluid containing $20 \%$ spectroscopic graded alcohol, $5 \mathrm{mM}$ potassium phosphate and $1 \mathrm{mM}$ EDTA at a tissue concentration of $100 \mathrm{mg} / \mathrm{mL}$ homogenizing mixture and centrifuged at $1000 \mathrm{r} / \mathrm{min}$ for 30 min in an ultracentrifuge at a constant temperature of $4{ }^{\circ} \mathrm{C}$. The supernatant was then used for assay. The activity was determined by the optical measurement of the rate of reduction of NAD. The reaction system contained in a final volume of $3 \mathrm{~mL}: 100 \mu \mathrm{M}$ NAD, $30 \mu \mathrm{g}$ of substrate of $3 \beta$ HSD or $17 \beta$ HSD as the case is each in $0.02 \mathrm{Ml}$ of purified doxin and a suitable quantity of enzyme (200$500 \mu \mathrm{L}$ ) to initiate the reaction. The final $\mathrm{pH}$ of the system was 9.1 . The reaction was carried out in silica cuvette of $1 \mathrm{~cm}$ light path, in a spectrophotometer (Shimadzu, UV-mini 1240) at $340 \mathrm{nM}$ absorbance. The activities were measured at $15 \mathrm{~s}$ intervals against a blank containing all components except steroids, linear initial velocities were determined graphically. One unit of enzyme activity is the amount causing change in absorbance of $0.001 / \mathrm{min}$ when enzymes serve as substrates. Quantitative assay of tissue protein was done by Lowry method[37].

\subsection{Enzymes linked immunosorbant assay of serum estradiol $\left(E_{2}\right)$ level, estriol $\left(E_{3}\right)$ level and progesterone level}

This assay employs the competitive inhibition enzyme immunoassay technique. A polyclonal antibody for goat anti-rabbit IgG had been pre-coated onto a microplate. Horseradish peroxidase (HRP) labelled human $\mathrm{E}_{2}$, unlabelled human $\mathrm{E}_{2}$ (standards or samples) and a polyclonal antibody for $E_{2}$ was added. Then the competitive inhibition reaction was launched between HRP labelled $\mathrm{E}_{2}$ and unlabelled human $\mathrm{E}_{2}$ with the antibody. Next, a TMB substrate solution was added to each well and a change in colour was exhibited. More the amount of human $\mathrm{E}_{2}$ present in the samples, lesser the HRP labelled human $\mathrm{E}_{2}$ could bind to the antibody. The substrate solution was added to the wells respectively. A colour developed in reversal to the amount of human $\mathrm{E}_{2}$ bound in the initial step. The colour development was stopped and the intensity of the colour was measured at $450 \mathrm{~nm}$ as per manufacturer's protocol via kits obtained from bio vision life sciences. The $\mathrm{E}_{3}$ level is also measured by the above procedures.

Progesterone was assayed using ELISA kits obtained from Equipar Diagnostics, Italy as per manufacturer's method.

\subsection{Measurement of serum thyroxine $\left(T_{4}\right)$ and triiodothyronine $\left(T_{3}\right)$ and thyroid stimulating hormone (TSH)}

The serum obtained from the experimental and control group of animals were used to measure $\mathrm{T}_{4}$ and $\mathrm{T}_{3}$ by Enzyme Linked Immunoabsorbent assay (ELISA) kits obtained from RFCL Limited, India as per manufacturer's instructions.

Thyroid stimulating hormone level was measured using Cusabio
Biotech Limited, Rat TSH kit (Lot no.C0710270665) as per manufacturer's protocol, following principle of ELISA.

\subsection{Statistical analysis $[38,39]$}

Results were expressed as mean \pm SD. Significance of difference between the control and treated groups were estimated using student's two tail $t$-test. The level of significance was determined on the basis of $P$ values and the level of significance was tested at 0.05 .

\section{Results}

\subsection{Body weight}

There was a significant increase in body weight of BS fed animals in comparison to control animals (Table 1).

\subsection{Organ weight}

There was a significant increase in thyroid weight, however there was decrease in ovarian weight and uterine weight of BS fed animals when compared with control animals (Table 1).

Table 1

BS induced changes in body weight and organ weight of female rats $(n=6)$.

\begin{tabular}{|c|c|c|c|c|c|c|}
\hline Group & $\begin{array}{l}\text { Initial BW } \\
\text { (g) }\end{array}$ & $\begin{array}{c}\text { Gain } \\
\text { of BW } \\
(\%)\end{array}$ & $\begin{array}{c}\text { Final BW } \\
\text { (g) }\end{array}$ & $\begin{array}{c}\text { Weight } \\
\text { of thyroid } \\
(\mathrm{mg} / 100 \mathrm{~g} \\
\mathrm{BW})\end{array}$ & $\begin{array}{c}\text { Weight } \\
\text { of ovary } \\
(\mathrm{mg} / 100 \mathrm{~g} \\
\text { BW) }\end{array}$ & $\begin{array}{c}\text { Weight of } \\
\text { uterus } \\
\text { (mg/100 g } \\
\text { BW) }\end{array}$ \\
\hline
\end{tabular}

\begin{tabular}{llllll}
\hline Control $92.25 \pm 3.97$ & 22.62 & $113.12 \pm 1.12$ & $8.43 \pm 1.26$ & $75.23 \pm 0.71$ & $156.96 \pm 0.76$
\end{tabular} $\begin{array}{llllll}\text { BS fed } 96.44 \pm 3.02 & 40.41 & 135.42 \pm 1.23^{*} & 12.68 \pm 0.86 & 62.34 \pm 0.95^{*} & 138.21 \pm 0.91^{*}\end{array}$

BW: body weight. Values are expressed as mean \pm SD. A two tailed ' $t$ ' test was performed and the significant differences were found between control and treated groups $(P<0.05)$.

\subsection{Food consumption pattern}

No significant difference was found in food consumption rate in control $[(25.0 \pm 1.6) \mathrm{g} / \mathrm{d} / \mathrm{rat}]$ and BS fed animals $[(24.0 \pm 1.3) \mathrm{g} / \mathrm{d} / \mathrm{rat}]$, with only a slight decrease being noted in the BS fed group.

\subsection{Serum TSH and thyroid hormone levels}

A significant decrease in both serum $\mathrm{T}_{3}$ and $\mathrm{T}_{4}$ levels of BS fed animals was found on assessment with the control animals while serum TSH levels increased significantly in BS fed animals (Table 2).

Table 2

BS induced changes in serum $\mathrm{T}_{3}, \mathrm{~T}_{4}$, TSH levels, urinary iodine and thiocyanate levels $(n=6)$.

\begin{tabular}{lccccc}
\hline Group & $\begin{array}{c}\mathrm{TSH} \\
(\mu \mathrm{IU} / \mathrm{mL})\end{array}$ & $\begin{array}{c}\mathrm{T}_{4} \\
(\mu \mathrm{g} / \mathrm{dL})\end{array}$ & $\begin{array}{c}\mathrm{T}_{3} \\
(\mathrm{ng} / \mathrm{mL})\end{array}$ & $\begin{array}{c}\text { Urinary } \\
\text { iodine levels } \\
(\mu \mathrm{g} / \mathrm{dL})\end{array}$ & $\begin{array}{c}\text { Urinary } \\
\text { thiocyanate } \\
\text { levels }(\mathrm{mg} / \\
\mathrm{mL})\end{array}$ \\
\hline Control & $0.384 \pm 0.023$ & $6.72 \pm 0.71$ & $0.85 \pm 0.05$ & $35.26 \pm 1.63$ & $0.50 \pm 0.04$ \\
BS fed & $0.532 \pm 0.087^{*}$ & $4.67 \pm 0.54^{*}$ & $0.59 \pm 0.01^{*}$ & $42.87 \pm 0.97^{*}$ & $1.43 \pm 0.12^{*}$ \\
\hline Values are expressed as mean $\pm \mathrm{SD}$. A two tailed ' $t$ ' test was performed and the \\
significant differences were found between control and treated groups $(P<0.05)$.
\end{tabular}




\subsection{Urinary iodine and thiocyanate}

A significant increase in the levels of urinary iodine and thiocyanate was found in the BS fed group in comparison to the control group. (Table 2).

\section{6. $H S D s$}

There was a significant decrease in ovarian $\Delta^{5} 3 \beta$ HSD activity and ovarian $17 \beta$ HSD activity of BS fed animals when evaluated against the control animals (Table 3 ).

Table 3

BS induced changes in $3 \beta$ HSD, $17 \beta$ HSD activity and estradiol, progesterone levels $(n=6)$.

\begin{tabular}{lccccc}
\hline Group & $\begin{array}{c}3 \beta \text { HSD } \\
(\mathrm{OD} / \mathrm{min} / \mathrm{mg} \\
\text { of protein) }\end{array}$ & $\begin{array}{c}17 \beta \mathrm{HSD} \\
(\mathrm{OD} / \mathrm{min} / \mathrm{mg} \\
\text { of protein })\end{array}$ & $\begin{array}{c}\text { Estradiol } \\
(\mathrm{ng} / \mathrm{mL})\end{array}$ & $\begin{array}{c}\text { Estriol } \\
(\mathrm{ng} / \mathrm{mL})\end{array}$ & $\begin{array}{c}\text { Progesterone } \\
(\mathrm{ng} / \mathrm{mL})\end{array}$ \\
\hline Control & $0.100 \pm 0.010$ & $0.116 \pm 0.050$ & $78.15 \pm 1.47$ & $0.13 \pm 0.02$ & $43.00 \pm 1.52$ \\
BS fed & $0.061 \pm 0.003^{*}$ & $0.111 \pm 0.020^{*}$ & $71.52 \pm 1.58^{*}$ & $0.08 \pm 0.01^{*}$ & $31.00 \pm 1.83^{*}$ \\
\hline
\end{tabular}

\subsection{Serum estrogen and progesterone levels}

A significant decrease in serum estradiol $\left(E_{2}\right)$,estriol $\left(E_{3}\right)$ levels and progesterone levels (Table 3) of BS fed animals was found on assessment with the control animals.

\subsection{Estrous cycle}

The study of the vaginal smear for a period of $45 \mathrm{~d}$ shows that the animals of control group had regular $(5 \pm 1) \mathrm{d}$ of estrous cycle while in the BS fed group constant diestrous phase was observed almost on/from day 40 (Figure 1).

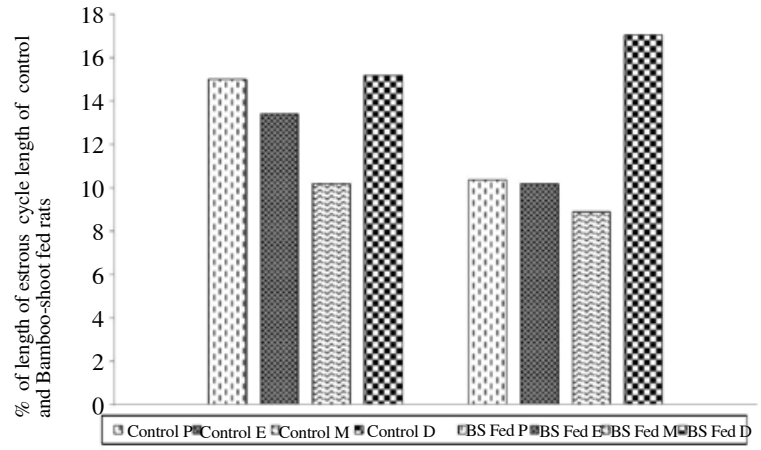

Figure 1. Percentage change in estrous stages induced by BS. $\mathrm{P}=$ Proestrous, $\mathrm{E}=$ Estrous, $\mathrm{M}=$ Metestrous, $\mathrm{D}=$ Diestrous

\subsection{Histology of thyroid, ovary and uterus}

The photomicrograph of the ovary revealed that in contrast to the control animals, the BS fed animals had degenerated thecal cells, disintegrated granulosa cells, followed by diminished cumulous oophorous and an immature oocyte (Figure 2).

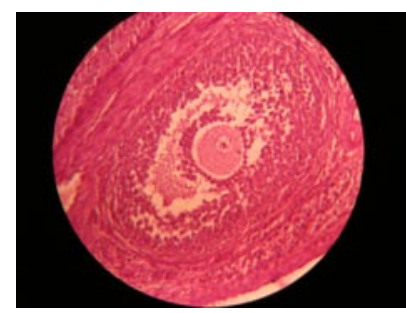

Control ovary

Figure 2. Photomicrographs of control and BS fed (after $45 \mathrm{~d}$ of consumption) ovary.

Haematoxylin and eosin stained. Magnification $400 \times$.

The uterine microphotograph showed that the BS fed animals had an increased perimetrium and endometrium, diminished uterine glands, an atrophied lumen and decreased stratum vasculare distinctly different from that of control animals (Figure 3).

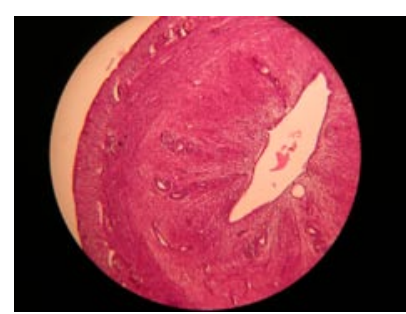

Control uterus

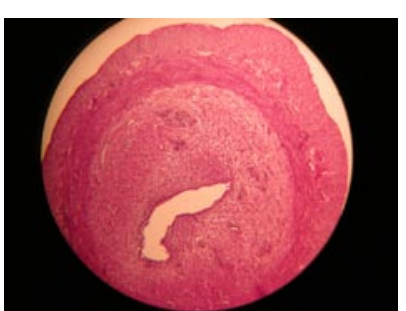

BS fed uterus
Figure 3. Photomicrograph of control and BS fed (after $45 \mathrm{~d}$ of consumption) uterus.

Haematoxylin and eosin stained. Magnification $100 \times$.

The photomicrograph of the thyroid of BS fed animals showed features similar of a hypothyroid state including irregularly-shaped follicles with decreased colloid content and hypertrophied and hyperplastic nature of follicular epithelial cells in contrast to evenly filled regular shaped follicles of the control animals (Figure 4).

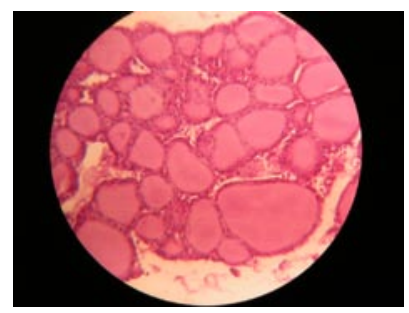

Control Thyroid

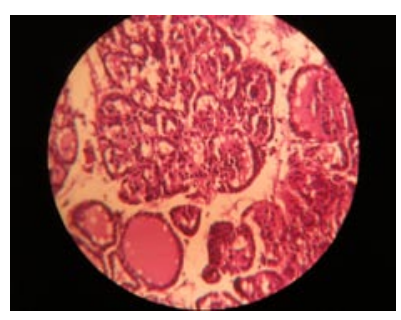

BS Fed Thyroid
Figure 4. Photomicrographs of control and BS fed (after $45 \mathrm{~d}$ of consumption) thyroid.

Haematoxylin and Eosin stained. Magnification $400 \times$.

\section{Discussion}

Commonly known for their industrial uses, a rare known fact of bamboos is the use of its young shoots as a food that can be eaten fresh, fermented, or canned. BS are now being utilized worldwide as a potential health food and as a nutraceutical due to its rich nutrient content. It contains carbohydrates $(5.70 \%)$, proteins $(3.90 \%)$, 
minerals $(1.10 \%)$ while several other essential components such as vitamins, amino acids, sterols, polyphenols and steroids can be extracted from it to a lesser extent[40]. BS however contains an approximate $600 \mathrm{mg} / \mathrm{kg}$ wet weight of cyanogenic glycosides of the taxiphyllin group, glucosinolates and thiocyanates[22]. All these are anti-thyroid components of naturally occurring goitrogenic plants and are capable of disrupting the bodies' ability to utilize iodine, blocking thyroid hormone synthesis and release[22]. Thus, being an established anti-thyroidal agent it is expected to bring about changes by perturbing balance of the hypothalamo-pituitary-thyroid axis and hypothalamo-pituitary-ovarian axis or by any of its several other components which in their way can impinge on the female reproductive functions. The present study evaluates certain changes in morphological and functional status of the female reproductive system that are liable to occur on BS consumption.

No significant changes was observed in the food consumption pattern of BS fed animals in conjunction to control animals indicating that there was no disparity in the amount of food intakes of both groups and that sufficient amount of goitrogens were consumed by BS fed animals.

Urinary iodine and thiocyanate levels both increased significantly in BS fed group in contrast to control animals. The cyanogenic glycosides and glucosinolates present in BS are readily converted to thiocyanates which appear in the blood and urine[22]. The free thiocyanate present in BS also adds to these levels. On the other hand thiocyanate is a well-established inhibitor of iodide in the thyroid gland, causing its excess efflux and appearance in urine[41]. Thus, elevated levels of iodine and thiocyanate in the urine are also markers of sufficient goitrogen consumption by the experimental group of animals. Current findings are consistent with previous studies which have reported similar increase in urinary iodine and thiocyanate levels on consumption of BS[22].

There was a significant increase in body weight and decrease of $\mathrm{T}_{3}, \mathrm{~T}_{4}$ levels and increase in TSH levels of BS fed animals in comparison to the control group. This effect could likely be due to the anti-thyroidal properties of BS which can induce hypothyroidism as patients with an underactive thyroid tend to have a very low basal metabolic rate; one of the most noticeable symptoms of hypothyroidism is weight gain and difficulty in losing extra weight[42]. Increase in TSH levels, thyroid weight as well as hyperplastic and hypertrophic nature of thyroid morphology on BS consumption are strong indicators of hypothyroidism induction[43]. A significant decrease in ovarian weight was also observed in comparison with the control group. A study on effect of rape seed (another natural goitrogen containing cyanogenic glycosides) on pig's female reproduction also showed that there is decrease in ovarian weight following its consumption[44]. On treatment with synthetic anti-thyroid drug like thiourea also decreases ovarian weight in Chinese hamsters[45].

The histological comparison of the control ovary with that of the BS fed ovary showed changes in the granulosa cells lining of the ovary, which lack discrete cellular arrangement. $\mathrm{T}_{3}$ receptors have been identified in the granulosa cells of ovary. It could be assumed that this impaired folliculogenesis is due to insufficient thyroid hormone production that hampers the differentiation and not the propagation of granulosa cells as suggested by Dijkstra et al.[46]. Certain parts of the ovarian lining in BS fed ovary were disrupted and thecal cells were degenerated. This could be due to decrease in estrogens level which are the primary steroid hormones in this region. Vice-versa, the estrogens concentration could have decreased due to the changes here. Absence of cumulous oophorous and decreased membrane granulosa were also the prominent features of the BS fed ovary in comparison to the control suggesting that there was less maturation of the oocyte for which the deficiency of oophorous found responsible.

There was a significant decrease in uterine weight in comparison with that of control. In a similar study cassava, a cruciferous vegetable containing cyanogenic glycosides was fed to rabbits and vaginal and left oviductal weight was reported to have decreased which are similar to weight reduction as observed in the present study[47]. It is also known that uterine regression is associated with a hypothyroid state and is also conspicuous in thyroidectomized female[42]. Available results suggest that thyroid hormones have a direct effect on the uterus which regulates the responsiveness of the organ to estradiol[48]. Thus, BS via its induction of a hypothyroid state impinges on the uterine weight and function.

The lumen of the BS fed uterus showed an atrophied appearance while the cellular mass in the endometrium and perimetrium were increased in respect of the control uterus. Uterus in hypothyroid sheep has been showed to have endometrial hyperplasia and smooth muscle hypertrophy[49]; a similar condition is probable to have occurred here. Stratum vasculare and uterine glands were declined in BS fed uterus in comparison to the control uterus. On treatment with PTU a drug which induces hypothyroidism and also on thyroidectomy in rats poorly developed uterus was seen[42]. Inuwa et al.[50] reported that absolute epithelial cell volume as well the height of the luminal epithelium in hypothyroid rats decreased but endometrium thickness was significantly increased. Thus it might be concluded that thyroid hormones might be importantly concerned in the maintenance of the normal structure of uterine epithelial cells. In the present study BS presumably affected the thyroid hormones and almost similar results have been documented.

$\Delta^{5} 3 \beta$ HSD activity in BS fed animals was significantly reduced than that of control animals. Flaxseed having similar constituents as that of BS reduced $\Delta^{5} 3 \beta$ HSD activity in males[51]. Glucosinolates present in Christmas Bush (Chromolaena odorata) plant similar to BS have also been reported to decrease LH, FSH, and testosterone as well as $\Delta^{5} 3 \beta$ HSD activity in males[52]. Thus, it may be assumed that such alterations have also been mediated in females. In accordance to $\Delta^{5} 3 \beta$ HSD, $17 \beta$ HSD activity also decreased significantly in experimental animals than in control animals. 17 $\beta$ HSD expression is controlled by gonadotrophins, androgens and estrogens themselves[53]. Constituents of BS like glucosinolates are known to decrease gonadotrophins and androgens[52] although these were not assayed in the present investigation but estrogen and progesterone levels were observed to decline. Consequently it may be presumed that $17 \beta$ HSD being under multihormonal control can 
be regulated by any of its modulators which themselves could be effected by BS constituents.

Both the serum estrogens and progesterone levels were decreased significantly in BS fed animals in comparison with control animals. A possible mechanism could be via phytosterols and dietary fibres which are present in BS. Phytosterols are the known effectors which decrease cholesterols and sex steroids in plasma[54,55]. Decrease in $\Delta^{5} 3 \beta$ HSD and $17 \beta$ HSD levels is also likely to have resulted in decreased conversion of precursors of progesterone and estrogens to the hormones themselves.

In this study, experimental animals were fed BS for $45 \mathrm{~d}$. The estrous cycle was regular till $(18 \pm 2) \mathrm{d}$, then became irregular, finally ceasing from day 40 at diestrous phase in the BS fed animals. Similar finding was reported by United States Government in relevance to public health[56]. It was stated there that on consumption of dietary cyanogens (also present in BS) there is prolongation of diestrous phase with reduction in estrous phase. This finding is also correlated with the fact that estrogens levels declined in the treated animals. Adult female rats, made hypothyroid, also reportedly have irregular estrous cycles and ovarian atrophy[57]. PTU treated hypothyroid animals also have been shown to have irregular cycles leading towards diestrous[58]. Thus changes in the estrous cycle observed in the study are consistent with those seen in hypothyroid conditions and substantiates the role of BS as a potent goitrogen.

The overall results reveal that BS consumption caused an increase in body weight and thyroid weight, decrease in ovarian weight along with a decrease in uterine weight followed by inhibition of $\Delta^{5} 3 \beta$ HSD and $17 \beta$ HSD activity and decrease of serum estriol, estradiol and progesterone levels. The estrous cycle was predominantly irregular and ceased at diestrous towards the end of the study. Therefore, BS either through its direct action or via its action as an anti-thyroid agent brings about some significant changes in female reproduction putting to question the regular, ubiquitous consumption of it as a health food. Degenerative changes were seen in both the uterus and ovary indicating that it has a disrupting role which could possibly lead to infertility in women. However, it is difficult to come to exact conclusive statements about its accurate regulating effect without measuring other essential parameters such as FSH, LH, aromatase, etc. Further studies along with in-vitro studies can shed more light into the role of BS consumption on female reproduction.

\section{Conflict of interest statement}

The authors declare that they have no conflict of interest.

\section{Acknowledgment}

First author Deotima Sarkar is grateful to DST INSPIRE Fellowship Scheme for fellowship.

\section{References}

[1] Peters Hannah, Kenneth P McNatty. The ovary: A correlation of structure and function in mammals. 1st ed. California: Univ of California Press; 1980, p. $12-21$

[2] Irianni F, Hodgen GD. Mechanism of ovulation. Endocrinol Metab Clin North 1992; 21(1): 19-38.

[3] Hall JE, Schoenfeld DA, Martin KA, Crowley Jr WF. Hypothalamic gonadotropin-releasing hormone secretion and follicle-stimulating hormone dynamics during the luteal-follicular transition. $J$ Clin Endocrinol Metab 1992; 74(3): 600-607.

[4] Gore AC, Yeung G, Morrison JH, Oung T. Neuroendocrine aging in the female rat: The changing relationship of hypothalamic gonadotropinreleasing hormone neurons and N-Methyl-d-Aspartate receptors. Endocrinology 2000; 141(12): 4757-4767.

[5] Chrousos GP, Torpy DJ, Gold PW. Interactions between the hypothalamic-pituitary-adrenal axis and the female reproductive system: Clinical implications. Ann Int Med 1998; 129(3): 229-240.

[6] Creatsas G, Mastorakos G, Chrousos GP. The young woman at the rise of the 21st century. Gynecological and reproductive issues in health and disease. Ann N Y Acad Sci 2000; 900: 1-446.

[7] Nicolopoulou-Stamati P, Pitsos MA. The impact of endocrine disrupters on the female reproductive system. Hum Reprod Update 2001; 7(3): 323330.

[8] Warren MP, Perlroth NE. The effects of intense exercise on the female reproductive system. J Endocrinol 2001; 170(1): 3-11.

[9] Gallo D, Cantelmo F, Distefano M, Ferlini C, Zannoni GF, Riva A, et al. Reproductive effects of dietary soy in female Wistar rats. Food Chem Toxicol 1999; 37(5): 493-502.

[10]Lobovikov M, Ball L, Guardia M, Russo L. World bamboo resources: A thematic study prepared in the framework of the global forest resources assessment 2005. Rome: Food and Agriculture Organization of the United Nations; 2007, p. 1-7.

[11]Bhargava A, Kumbhare V, Srivastava A, Sahai A. Bamboo parts and seeds for additional source of nutrition. J Food Sci Technol 1996; 33(2): 145-146.

[12]Choudhury D, Sahu JK, Sharma GD. Value addition to bamboo shoots: A review. J Food Sci Technol 2012; 49(4): 407-414.

[13]Nirmala C, Sharma ML, David E. A comparative study of nutrient components of freshly harvested, fermented and canned bamboo shoots of dendrocalamusgiganteusmunro. World Bamb Ratt 2009; 1: 31.

[14]Nongdam P, Tikendra L. The nutritional facts of bamboo shoots and their usage as important traditional foods of Northeast India. Int Sch Res Notices 2014; 679073. doi: 10.1155/2014/679073.

[15]Sarangthem K, Singh TN. Microbial bioconversion of metabolites from fermented succulent bamboo shoots into phytosterols. Cur Sci Bangalore 2003; 84(12): 1544-1546.

[16]Lachance PA, He YH. Hypocholesterolemic compositions from bamboo shoots. US Patent No. WO/1998/057545 (patent); 1998.

[17]Park EJ, Jhon DY. Effects of bamboo shoot consumption on lipid profiles and bowel function in healthy young women. Nutrition 2009; 25(7): 723728.

[18]Park EJ, Jhon DY. The antioxidant, angiotensin converting enzyme inhibition activity, and phenolic compounds of bamboo shoot extracts. LWT-Food Sci Technol 2010; 43(4): 655-659. 
[19]Tripathi YC, Kaushik PK, Bhuyan TC. Sustainable development of quality bamboo resource for employment generation and socio-economic development in NE India. Jorhat: Rain Forest Research Institute; 2013, p. 11-13.

[20]Bradford PG, Awad AB. Phytosterols as anticancer compounds. Mol Nutr Food Res 2007; 51(2): 161-170.

[21]Anonymous. Cyanogenic glycosides in cassava and bamboo shoots, a human health risk assessment. Technical report series no. 28. Food Standards Australia New Zealand; 2004.

[22]Chandra AK, Ghosh D, Mukhopadhyay S, Tripathy S. Effect of bamboo shoot, Bambusa arundinacea (Retz.) Wild. On thyroid status under conditions of varying iodine intake in rats. Indian J Exp Biol 2004; 42(8): 781-786.

[23]Chandra A, Singh L, Ghosh S, Pearce E. Role of bamboo-shoot in the pathogenesis of endemic goiter in Manipur, North East India. Endocr Pract 2012; 9(1): 36-45.

[24]Yen SSC. Chronic anovulation caused by peripheral endocrine disorders. In Yen SSC, Jaffe RB, editors. Reproductive endocrinology. Philadelphia: W.B. Saunders; 1986, p. 441-499.

[25]Davis LE, Leveno KJ, Cunningham FG. Hypothyroidism complicating pregnancy. J Obstet Gynaecol 1988; 72(1): 108-112.

[26]Dittrich R, Beckmann MW, Oppelt PG, Hoffmann I, Lotz L, Kuwert T, et al. Thyroid hormone receptors and reproduction. J Reprod Immunol 2011; 90(1): 58-66.

[27]Vanithakumari G, Manonayagi S, Padma S, Malini T. Anti fertility effect of Bambusa arundinacea shoot extracts in male rats. J Ethno Pharmacol 1989; 25(2): 173-180.

[28]Kalita T, Dutta U. A comparative study on indigenous usage of bamboo shoot in the health care practices in NE India. Clarion Intmultid $J$ 2012; 1(2); 130-141.

[29]Chandra AK, Ghosh R, Chatterjee A, Sarkar M. Effects of vanadate on male rat reproductive tract histology, oxidative stress markers and androgenic enzyme activities. J Inorg Biochem 2007; 101(6): 944-956.

[30]Chakraborty A, Mondal C, Sinha S, Mandal J, Chandra AK. Amiodarone induced oxidative stress in stress-vulnerable organs of adult male rats. Asian J Pharm Clin Res 2014; 7(4): 177-183.

[31]Karmarkar MG, Pandav CS, Krishnamachari KAVR. Principle and procedure for iodine estimation-A laboratory manual. New Delhi: Indian Council of Medical Research; 1986, p. 1-14.

[32]Aldridge WN. The estimation of micro quantities of cyanide and thiocyanate. Analyst (London) 1945; 70: 474-475.

[33]Michajlovskij N, Langer P. Studienuber Benziehungenzwischen Rhodanbildung und Kropfbildender Eigenschaft von Nahrungsmitteln. In: Gehalteiniger Nahrungsmittel and praformierten Rhodanid. Z Physiol Chem 1958; 312: 26-30.

[34]Paccola CC, Resende CG, Stumpp T, Miraglia SM, Cipriano I. The rat estrous cycle revisited: A quantitative and qualitative analysis. Anim Reprod 2013; 10: 677-683.

[35]Payne DW, Talalay P. Isolation of novel microbial 3 alpha-, 3 beta-, and 17 beta-hydroxysteroid dehydrogenases. Purification, characterization, and analytical applications of a 17 beta-hydroxysteroid dehydrogenase from an Alcaligenes sp. J Biol Chem 1985; 260(25): 13648-13655.

[36]Jarabak J, Adams JA, Williams-Ashman HG, Talalay P. Purification of a 17 beta-hydroxysteroid dehydrogenase of human placenta and studies on its transhydrogenase function. J Biol Chem 1962; 237: 345-357.

[37]Lowry OH, Rosebrough NJ, Farr AL, Randall RJ. Protein measurement with the Folin phenol reagent. J Biol Chem 1951; 193(1): 265-275.

[38]Van Belle G, Fisher LD, Heagerty PJ, Lumley T. Biostatistics: A methodology for the health sciences. MA: John Wiley \& Sons; 2004, p.
131-150.

[39]Stats V. Website for Statistical Computation; 2015.

[40]Gopalan C, Ramasastri BV, Balasubramanian SC. Nutritive value of Indian foods, National Institute of nutrition, Hyderabad. New Delhi: Indian Council of Medical Research; 1984, p. 66-117.

[41]Chandra AK. Iodine, thiocyanate and the thyroid. Biochem Pharmacol (Los Angel) 2015; 4(171): 2167-2501.

[42]Chang YJ, Hwu CM, Yeh CC, Wang PS, Wang SW. Effects of sub-acute hypothyroidism on metabolism and growth-related molecules. Molecules 2014; 19(8): 11178-11195.

[43]Chandra AK, De N. Catechin induced modulation in the activities of thyroid hormone synthesizing enzymes leading to hypothyroidism. Mol Cell Biochem 2013; 374(1-2): 37-48.

[44]Nordfeldt S, Gellerstedt N, Falkmer S. Studies on rape seed meal and its goitrogenic effect on pigs. Acta Pathol Microbiol Scand 1954; 35(3): 217 236.

[45]Reiter RJ, Hoffman RA, Hester RJ. The effects of thiourea, photoperiod and the pineal gland on the thyroid, adrenal and reproductive organs of female hamsters. J Exp Zool 1966; 162(3): 263-268.

[46]Dijkstra G, de Rooij DG, De Jong FH, Van Den Hurk R. Effect of hypothyroidism on ovarian follicular development, granulosa cell proliferation and peripheral hormone levels in the prepubertal rat. Eur J Endocrinol 1996; 134(5): 649-654.

[47]Omole TA. The use of cassava feeding rabbits. Mortality 1992; 25: 12-50.

[48]Kirkland JL, Gardner RM, Mukku VR, Akhtar M, Stancel GM. Hormonal control of uterine growth: The effect of hypothyroidism on estrogen-stimulated cell division. Endocrinology 1981; 108(6): 23462351.

[49]Krassas GE, Poppe K, Glinoer D. Thyroid function and human reproductive health. Endocr Rev 2010; 31(5): 702-755.

[50]Inuwa I, Williams MA. Morphometric study on the uterine horn and thyroid gland in hypothyroid, and thyroxine treated hypothyroid rats. $J$ Anat 1996; 188(2): 383.

[51]Sprando RL, Collins TF, Wiesenfeld PW, Thompson LU, Cunnane SC. Effect of flaxseed consumption on male and female reproductive function and fetal development. Flaxs Hum Nutr 2003; 341-362.

[52]Yakubu MT. Effect of a 60-day oral gavage of a crude alkaloid extract from chromolaenaodorata leaves on hormonal and spermatogenic indices of male rats. J Androl 2012; 33(6): 1199-1207.

[53]Ghersevich S, Poutanen M, Tapanainen J, Vihko R. Hormonal regulation of rat 17 beta-hydroxysteroid dehydrogenase type 1 in cultured rat granulosa cells: Effects of recombinant follicle-stimulating hormone, estrogens, androgens, and epidermal growth factor. Endocrinology 1994; 135(5): 1963-1971.

[54]Bassett JD, Williams GR. The molecular actions of thyroid hormone in bone. Trends Endocrinol Metab 2003; 14(8): 356-364.

[55]Gilman CI, Leusch FD, Breckenridge WC, MacLatchy DL. Effects of a phytosterol mixture on male fish plasma lipoprotein fractions and testis P450 scc activity. Gen Comp Endocrinol 2003; 130(2): 172-184.

[56]Relevance to public health in Agency for toxic substances and disease registry. [Online]Available from: http://www.atsdr.cdc.gov/ToxProfiles/ tp153-c2.pdf.

[57]Hatsuta M, Abe K, Tamura K, Ryuno T, Watanabe G, Taya K, et al. Effects of hypothyroidism on the estrous cycle and reproductive hormones in mature female rat. Eur J Pharmacol 2004; 486(3): 343-348.

[58]Armada-Dias L, Carvalho JJ, Breitenbach MMD, Franci CR, Moura EG Is the infertility in hypothyroidism mainly due to ovarian or pituitary functional changes? Braz J Med Biol Res 2001; 34(9): 1209-1215. 